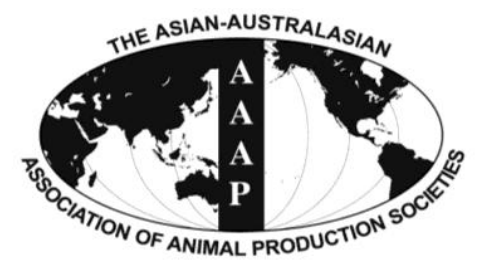

Asian-Aust. J. Anim. Sci.

Vol. 25, No. $10: 1430$ - 1438

October 2012

www.ajas.info

http://dx.doi.org/10.5713/ajas.2012.12201

\title{
Evaluation of Energy Digestibility and Prediction of Digestible and Metabolizable Energy from Chemical Composition of Different Cottonseed Meal Sources Fed to Growing Pigs
}

\author{
J. T. Li, D. F. Li, J. J. Zang, W. J. Yang, W. J. Zhang and L. Y. Zhang* \\ State Key Laboratory of Animal Nutrition, China Agricultural University, \\ No. 2 Yuanmingyuan West Road, Beijing, 100193, China
}

\begin{abstract}
The present experiment was conducted to determine the digestible energy (DE), metabolizable energy (ME) content, and the apparent total tract digestibility (ATTD) of energy in growing pigs fed diets containing one of ten cottonseed meals (CSM) collected from different provinces of China and to develop in vitro prediction equations for DE and ME content from chemical composition of the CSM samples. Twelve growing barrows with an initial body weight of $35.2 \pm 1.7 \mathrm{~kg}$ were allotted to two $6 \times 6$ Latin square designs, with six barrows and six periods and six diets for each. A corn-dehulled soybean meal diet was used as the basal diet, and the other ten diets were formulated with corn, dehulled soybean meal and 19.20\% CSM. The DE, ME and ATTD of gross energy among different CSM sources varied largely and ranged from 1,856 to $2,730 \mathrm{kcal} / \mathrm{kg}$ dry matter (DM), 1,778 to $2,534 \mathrm{kcal} / \mathrm{kg}$ DM, and 42.08 to $60.47 \%$, respectively. Several chemical parameters were identified to predict the DE and ME values of CSM, and the accuracy of prediction models were also tested. The best fit equations were: $\mathrm{DE}, \mathrm{kcal} / \mathrm{kg} \mathrm{DM}=670.14+31.12 \mathrm{CP}+659.15 \mathrm{EE}$ with $\mathrm{R}^{2}=0.82, \mathrm{RSD}$ $=172.02, \mathrm{p}<0.05$; and $\mathrm{ME}, \mathrm{kcal} / \mathrm{kg} \mathrm{DM}=843.98+25.03 \mathrm{CP}+673.97 \mathrm{EE}$ with $\mathrm{R}^{2}=0.84, \mathrm{RSD}=144.79, \mathrm{p}<0.05$. These results indicate that DE, ME values and ATTD of gross energy varied substantially among different CSM sources, and that some prediction equations can be applied to predict DE and ME in CSM with an acceptable accuracy. (Key Words: Cottonseed Meals, DE, ME, Growing Pigs, Prediction Equations)
\end{abstract}

\section{INTRODUCTION}

Cotton is not only a major fibrous crop, but also the second most important oil and protein crop after soybean in the world. For every $100 \mathrm{~kg}$ of cotton fiber produced, the cotton plant also yields approximately $160 \mathrm{~kg}$ of cottonseed. China is the world's largest cotton and cottonseed producing country. Cottonseed meal (CSM) is a co-product of the cottonseed oil processing industry. With processing, typical yields from cottonseed are 50\% meal, $22 \%$ hulls, $16 \%$ oil, $7 \%$ linters, with a $5 \%$ loss. Cottonseed meal is the third most widely traded protein ingredient after soybean meal and rapeseed meal, which represents a $7.10 \%$ of the world protein meal production, reaching 14.45 million metric tons in 2004 and 2005 (Ash and Dohlman, 2006). With the increasingly severe shortage of protein resources, cottonseed meal as a nontraditional protein feed ingredient

\footnotetext{
* Corresponding Author: Liying Zhang. Tel: +86-10-6273-1272, Fax: +86-10-6273-3688, E-mail: zhangliying01@ sina.com Submitted Mar. 2, 2012; Accepted Jun. 7, 2012; Revised Jun. 11, 2012
}

has drawn more and more attention from livestock producers. Although much of the cottonseed meal is utilized in ruminant diets (Brown and Pate, 1997; Cranston et al., 2006; Winterholler et al., 2009), the price of cottonseed meal compared with other high-protein feedstuffs could provide an excellent opportunity for pork producers to reduce feed costs (Tanksley, 1990). In previous studies, cottonseed meal has been used effectively at low levels in the growing pig diets (Robison, 1931; Papadopoulos et al., 1987; Fombad and Bryant, 2004). However, due to the different cotton varieties, planting environment, and cottonseed processing methods, the nutrient levels vary largely among different sources of cottonseed meals, especially with regard to crude protein and crude fiber. In addition, due to the different temperature and organic solvent used in cottonseed processing, there is also a big difference in the content of free gossypol which is the main anti-nutritional factor in cottonseed meal. All these factors seriously restrict the reasonable application of cottonseed meal in animal feed. Therefore, it is necessary to determine 
the actual nutrient content in cottonseed meal, especially for available nutrient content.

As a common protein supplement source of animal feed, there have been many reports on the protein and amino acid digestibility of cottonseed meal (Tanksley et al., 1981; Knabe et al., 1989; Batterham et al., 1990). However, limited data were found on the energy value of cottonseed meal in pigs. Only Husby and Kroening (1971) gave a relatively detailed study on the energy value of cottonseed meal for pigs. Therefore, in order to make better use of cottonseed meal raw materials and to achieve the accurate preparation of feed, it is necessary to evaluate the energy value of cottonseed meal in pigs.

At present, the evaluation of the energy value of feed ingredients is made mainly through the traditional digestion and metabolism experiment, which is time consuming, labor intensive, and expensive. Therefore, it is essential to establish a rapid and accurate method to measure the energy value of feed ingredients. Given these challenges, however, prediction equations are a useful tool in estimating the energy value of feed ingredients utilized in the livestock industry. Although some models were established for complete diets (Noblet and Perez, 1993), barley (Fairbairn et al., 1999), sweet lupins (Kim et al., 2009), wheat-DDGS (Cozannet et al., 2010), and corn co-products (Anderson et al., 2012), to our knowledge, there have been no such equations generated for predicting digestible energy (DE) and metabolizable energy (ME) values of CSM fed to growing pigs. Therefore, the objectives of this study were to determine the energy digestibility and prediction of DE and ME value based on the chemical composition of CSM fed to growing pigs.

\section{MATERIALS AND METHODS}

All procedures used in the present experiment were approved by the Animal Care and Use Committee of China Agriculture University (Beijing, China).

\section{General procedures}

Ten CSM samples were obtained from different regions located in the main cotton producing areas of China and were all produced from cottonseed by pre-press extraction in local cottonseed oil processing plants. The chemical composition of different CSM sources was showed in Table 1.

The metabolic experiment was conducted in Metabolism Laboratory of Ministry of Agriculture Feed Industry Center (China Agricultural University, Beijing, China). Pigs were housed individually in stainless steel metabolism cages $(1.4 \times 0.45 \times 0.6 \mathrm{~m})$ in an environmentally controlled room $\left(22 \pm 2^{\circ} \mathrm{C}\right)$. Twelve growing crossbred barrows [(Yorkshire $\times$ Landrace $) \times$ Duroc] with initial body weight $(35.2 \pm 1.7) \mathrm{kg}$ and $90 \mathrm{~d}$ of age were allotted to two $6 \times 6$ Latin square designs, with six barrows and six periods and six diets for each. At the end of this experiment, the final body weight of the pigs was $(74.8 \pm 2.3) \mathrm{kg}$.

All the diets used in this experiment were prepared based on the chemical composition of feed ingredients. The basal diet was formulated to meet or exceed NRC (1998) nutrient requirements for growing pigs. Ten experimental diets were formulated based on the difference method (Adeola, 2001), and contained $61.84 \%$ corn, $14.88 \%$ dehulled soybean meal and $0.08 \%$ L-lysine- $\mathrm{HCl}$, which was equal to $80 \%$ of these ingredients in the basal diet, and $19.2 \%$ CSM which replaced $20 \%$ of the energy supplied by

Table 1. Analyzed composition of the ten cottonseed meal (CSM) sources (as dry matter basis)

\begin{tabular}{|c|c|c|c|c|c|c|c|c|c|c|}
\hline \multirow{2}{*}{ Items $^{2}$} & \multicolumn{10}{|c|}{ CSM source $^{1}$} \\
\hline & 1 & 2 & 3 & 4 & 5 & 6 & 7 & 8 & 9 & 10 \\
\hline Moisture (\%) & 9.18 & 9.30 & 8.97 & 9.17 & 8.43 & 8.98 & 8.68 & 8.83 & 10.67 & 8.53 \\
\hline Crude protein $(\%)$ & 50.85 & 34.35 & 46.66 & 46.35 & 40.78 & 41.65 & 47.11 & 47.22 & 49.64 & 54.01 \\
\hline Ether extract (\%) & 0.30 & 0.03 & 0.16 & 0.15 & 0.39 & 0.04 & 0.47 & 0.30 & 0.60 & 0.50 \\
\hline $\operatorname{NDF}(\%)$ & 29.56 & 46.94 & 33.40 & 30.37 & 33.71 & 38.12 & 31.51 & 32.31 & 30.11 & 27.90 \\
\hline $\operatorname{ADF}(\%)$ & 18.04 & 31.24 & 21.78 & 20.13 & 21.47 & 25.24 & 21.51 & 20.60 & 20.22 & 16.49 \\
\hline $\operatorname{ADL}(\%)$ & 8.81 & 16.88 & 11.81 & 10.98 & 12.03 & 11.28 & 9.35 & 9.33 & 8.23 & 6.11 \\
\hline Ash (\%) & 6.88 & 7.06 & 6.93 & 6.54 & 6.80 & 6.96 & 6.75 & 6.69 & 6.72 & 6.67 \\
\hline Calcium (\%) & 0.21 & 0.19 & 0.29 & 0.30 & 0.23 & 0.25 & 0.22 & 0.26 & 0.31 & 0.32 \\
\hline $\mathrm{TP}(\%)$ & 0.42 & 0.36 & 0.45 & 0.46 & 0.71 & 0.96 & 0.97 & 0.98 & 0.96 & 1.03 \\
\hline Phy-P (\%) & 0.30 & 0.27 & 0.29 & 0.31 & 0.48 & 0.69 & 0.68 & 0.70 & 0.66 & 0.73 \\
\hline $\mathrm{FG}(\mathrm{mg} / \mathrm{kg})$ & 214.3 & 265.47 & 268.45 & 222.22 & 279.98 & 244.69 & 395.05 & 346.60 & 336.02 & 302.32 \\
\hline GE (kcal/kg) & 4,543 & 4,445 & 4,532 & 4,445 & 4,455 & 4,486 & 4,565 & 4,517 & 4,514 & 4,602 \\
\hline
\end{tabular}

${ }^{1}$ Source 1, 2, 3, 4, 5, 6, 7, 8, 9 and 10 were collected from Shandong, Shanxi, Hubei, Hunan, Sichuan, Henan, Hebei, Xinjiang, Anhui, and Liaoning province of China, respectively.

${ }^{2} \mathrm{NDF}=$ Neutral detergent fiber; $\mathrm{ADF}=$ Acid detergent fiber; $\mathrm{ADL}=$ Acid detergent lignin; $\mathrm{TP}=$ Total phosphorus; $\mathrm{Phy}-\mathrm{P}=\mathrm{Phytate}$ phosphorus $; \mathrm{FG}=$ Free gossypol; GE = Gross energy. 
corn, dehulled soybean meal and L-lysine-HCl in the basal diet. The composition and nutrient levels of experimental diets were showed in Table 2 and 3.

The daily feed allowance was equivalent to $4 \%$ of body weight at the beginning of each period (Adeola, 2001). It was divided into two equal parts and fed at 08:00 and 17:00 $\mathrm{h}$ in mash form. Water was available ad libitum through a drinking nipple. The pigs were weighed individually at the beginning of each period and the amount of feed supplied each day was recorded, as well as any feed refusals. During each period, d 1 to 5 was adaptation phase and d 6 to 10 was collection phase in which feces and urine were collected totally. The collection and sample preparation of feces and urine were conducted according to the methods described by Song et al. (2003). Feces and urine samples were thawed and mixed uniformly for each pig at the end of the experiment, and representative subsamples were taken for chemical analysis. Feces samples were dried in a vacuum-freeze dryer (Tofflon Freezing Drying Systems, Minhang District, Shanghai, China), ground through a 1 mm screen, and thoroughly mixed before a subsample was collected for chemical analysis.

\section{Chemical analysis}

The ingredients used in this experiment were analyzed for dry matter (DM) (AOAC procedure 4.1.06, 2000), crude protein (CP) (AOAC procedure 990.03, 2000), Kjeldahl N (Thiex et al., 2002), ether extract (EE) (Thiex et al., 2003), ash (AOAC procedure 3.4.11, 2000), calcium (Ca) (AOAC procedure 4.8.03, 2000), total phosphorus (TP) (AOAC procedure 3.4.11, 2000), acid detergent lignin (ADL) (AOAC procedure 973.18, 2000). Phytate phosphorus was determined by colorimetric method of Wheeler and Ferrel (1971) as modified by Reddy et al. (1978). Neutral detergent fiber (NDF) and acid detergent fiber (ADF) were determined using filter bags and fiber analyzer equipment (Fiber Analyzer, Ankom Technology, Macedon, NY, USA)
Table 2. Composition of the experimental diets (\%, as-fed basis)

\begin{tabular}{lcc}
\hline Items & Basal diet & Basal diet+CSM $^{1}$ \\
\hline Corn & 77.30 & 61.84 \\
Dehulled soybean meal & 18.60 & 14.88 \\
CSM $^{1}$ & 0.00 & 19.20 \\
L-lysine-HCl $^{2}$ & 0.10 & 0.08 \\
Medical stone $^{2}$ & 0.90 & 0.90 \\
Dicalcium phosphate & 0.90 & 0.90 \\
Limestone & 0.90 & 0.90 \\
Sodium chloride & 0.30 & 0.30 \\
Vitamin and mineral premix $^{3}$ & 1.00 & 1.00 \\
Total & 100.00 & 100.00 \\
\hline
\end{tabular}

${ }^{1} \mathrm{CSM}=$ Cottonseed meal .

2 Medical stone consisted of silicon oxide and aluminium oxide, purchased by YiXian BeiQiao Tou Ore Company Limited.

${ }^{3}$ Provided per kg of complete diet: Vit A, 6,000 IU; Vit $\mathrm{D}_{3}, 2,400 \mathrm{IU}$; Vit E, 21.6 IU; Vit $\mathrm{K}_{3}, 2 \mathrm{mg}$; Vit $\mathrm{B}_{1}, 0.96 \mathrm{mg}$; Vit $\mathrm{B}_{2}, 5.2 \mathrm{mg}$; Vit $\mathrm{B}_{6}, 2 \mathrm{mg}$; Vit $B_{12}, 12 \mu \mathrm{g}$; Nicotinic acid, $22 \mathrm{mg}$; Pantothenic acid, $11.2 \mathrm{mg}$; Folic acid, $0.4 \mathrm{mg}$; Biotin, $40 \mu \mathrm{g}$; Choline chloride, $0.4 \mathrm{~g}$; Iron, $120 \mathrm{mg}$; Copper, $140 \mathrm{mg}$; Zinc, $100 \mathrm{mg}$; Manganese, $16 \mathrm{mg}$; Iodine, $0.24 \mathrm{mg}$; Selenium, $0.4 \mathrm{mg}$; Calcium, $7.2 \mathrm{~g}$; Phosphorus, $0.8 \mathrm{~g}$; Sodium chloride, $4.4 \mathrm{~g}$.

following a modification of the procedure of Van Soest et al. (1991). Free gossypol was determined according to the method described by Pons and Guthrie (1949). The gross energy (GE) in CSM, diets, feces, and urine samples was analyzed via adiabatic oxygen bomb calorimeter (Parr Instruments, Moline, IL, USA).

\section{Calculations}

The energy lost in feces and urine was determined for each diet, and the DE and ME values of ten different CSM diets were calculated. The DE and ME in the basal diet was then divided by 0.96 to calculate the $\mathrm{DE}$ and $\mathrm{ME}$ in the energy-contributing ingredients (including corn, dehulled soybean meal and L-lysine-HCl) according to Gottlob et al. (2006). After that, the DE and ME values contributed by

Table 3. Analyzed nutrient composition of the experimental diets (\%, as-fed basis)

\begin{tabular}{|c|c|c|c|c|c|c|c|c|c|c|c|}
\hline \multirow{2}{*}{ Items $^{2}$} & \multicolumn{11}{|c|}{ Cottonseed meal source $^{1}$} \\
\hline & Basal diet & 1 & 2 & 3 & 4 & 5 & 6 & 7 & 8 & 9 & 10 \\
\hline Dry matter & 88.24 & 89.58 & 89.04 & 89.03 & 89.66 & 89.94 & 89.83 & 89.25 & 89.49 & 87.94 & 88.31 \\
\hline Crude protein & 15.18 & 20.55 & 17.43 & 19.83 & 21.18 & 19.40 & 20.81 & 20.87 & 21.17 & 20.83 & 20.63 \\
\hline Ether extract & 0.97 & 1.05 & 0.91 & 1.06 & 1.39 & 1.34 & 1.08 & 1.08 & 1.25 & 1.82 & 1.76 \\
\hline Crude fiber & 1.89 & 4.12 & 5.42 & 4.77 & 4.35 & 4.83 & 5.32 & 5.29 & 4.86 & 4.52 & 3.64 \\
\hline $\mathrm{NDF}$ & 8.01 & 12.10 & 14.13 & 13.86 & 12.56 & 6.34 & 14.30 & 14.52 & 13.96 & 13.91 & 12.54 \\
\hline $\mathrm{ADF}$ & 2.31 & 5.88 & 6.96 & 6.66 & 5.77 & 7.48 & 6.98 & 7.06 & 6.46 & 7.43 & 5.85 \\
\hline Calcium & 0.65 & 0.68 & 0.68 & 0.71 & 0.68 & 0.83 & 0.69 & 0.66 & 0.70 & 0.75 & 0.78 \\
\hline Phosphorus & 0.41 & 0.55 & 0.50 & .58 & 0.57 & 0.54 & 0.53 & 0.52 & 0.55 & 0.57 & 0.56 \\
\hline Ash & 5.11 & 5.88 & 5.80 & 6.12 & 5.78 & 6.33 & 6.12 & 5.97 & 6.08 & 5.55 & 5.65 \\
\hline GE (kcal/kg) & 3,850 & 3,800 & 3,770 & 3,790 & 3,830 & 3,820 & 3,800 & 3,820 & 3,810 & 3,800 & 3,780 \\
\hline
\end{tabular}


each CSM sample were calculated by subtracting the DE and $\mathrm{ME}$ values contributed by the basal energy-contributing ingredients according to the difference procedure (Adeola, 2001). N-balance of each diet was also calculated. The apparent total tract digestibility (ATTD) of energy and $\mathrm{N}$ of each diet and each source of CSM were calculated by the method of Adeola (2001).

\section{Statistical analysis}

Data were analyzed statistically using the Proc GLM procedure of SAS (SAS Inst. Inc., NC, USA). Each pig was considered as an experimental unit. The data from ten CSM sources were compared by ANOVA using the MIXED procedure of SAS (Littell et al., 1998). Mean comparisons were calculated using the PDIFF option of the LSMEANS procedure. A probability of $\mathrm{p}<0.05$ was accepted as statistically significant. The relationship between chemical composition and DE, ME were analyzed using the CORR and REG procedures of SAS (SAS, 1999).

\section{RESULTS}

\section{Chemical composition of CSM sources}

The chemical composition of ten CSM sources was showed in Table 1. On a dry matter basis, the concentration ranged from 34.35 to $54.01 \%, 0.03$ to $0.60 \%, 29.56$ to $47.90 \%, 16.49 \%$ to $31.24 \%, 6.11$ to $16.88 \%, 5.73$ to $7.06 \%$, 0.19 to $0.32 \%, 0.36$ to $1.03 \%$ for CP, EE, NDF, ADF, ADL, ash, $\mathrm{Ca}$, and TP, respectively. The content of GE was similar among different sources, while the content of free gossypol ranged from 214.30 to $395.05 \mathrm{mg} / \mathrm{kg}$. Small differences in nutrient levels were observed between sources 3 and 4, as well as between sources 7 and 8 . The sources 4 and 8 were chosen as the validation samples to test the accuracy of prediction models, while the remaining 8 sources were used as calibration samples.

\section{Energy and nitrogen digestibility}

The amount of energy excreted from feces of the diet containing source 6 was $1,148 \mathrm{kcal}$, which was higher $(\mathrm{p}<0.0001)$ than that of any other CSM diets (Table 4). However, there were no significant differences in the amount of energy excreted from urine. The DE, ME and ATTD of GE were similar among the diets containing different CSM sources.

The GE intake and amount of energy excreted from urine for pigs fed basal diet were not different from those of pigs fed CSM diets. However, pigs fed CSM diets excreted more $(\mathrm{p}<0.0001)$ energy from the feces than that of pigs fed the basal diet. On the contrary, the DE, ME and ATTD of GE of basal diet were greater $(p<0.05)$ than those of CSM diets.

Although the amount of $\mathrm{N}$ intake $(\mathrm{p}<0.0001)$ and $\mathrm{N}$ excreted from feces $(\mathrm{p}<0.05)$ were different among the diets containing different CSM sources, no differences in the amount of $\mathrm{N}$ excreted from the urine, ATTD of $\mathrm{N}$, and $\mathrm{N}$ retention were observed. However, pigs fed basal diet had lower $(\mathrm{p}<0.0001) \mathrm{N}$ excretion from feces than that of pigs fed CSM diets, and they also had a tendency to lower $(\mathrm{p}=$ $0.0577) \mathrm{N}$ excretion from urine and greater $(\mathrm{p}=0.0535)$ ATTD of $\mathrm{N}$.

The DE, ME, and ATTD of GE were all different $(p<0.05)$ among the ten CSM collected from different regions of China, which ranged from 1,856 to $2,730 \mathrm{kcal} / \mathrm{kg}$ $\mathrm{DM}, 1,778$ to $2,534 \mathrm{kcal} / \mathrm{kg} \mathrm{DM}$, and 41.37 to $60.47 \%$, respectively (Table 5). However, there was no difference in the ratio of ME to DE among the ten CSM sources.

\section{Correlations and prediction equations}

Fiber and ash had a negative correlation with DE and $\mathrm{ME}$, while the $\mathrm{CP}$ and EE content were positively correlated with DE and ME ( $\mathrm{p}$ <0.05) (Table 6). The best single predictor for $\mathrm{DE}$ and $\mathrm{ME}$ was the $\mathrm{CP}$ content, having the highest correlation coefficient $(0.73$ and 0.72 for $\mathrm{DE}$ and

Table 4. Daily energy and $\mathrm{N}$ balances for growing pigs fed basal diet and cottonseed meal (CSM) diets (as-fed basis)

\begin{tabular}{|c|c|c|c|c|c|c|c|c|c|c|c|c|c|c|c|}
\hline \multirow{2}{*}{ Items $^{2}$} & \multicolumn{10}{|c|}{ CSM diet ${ }^{1}$} & \multirow{2}{*}{$\begin{array}{c}\text { Basal } \\
\text { diet }\end{array}$} & \multicolumn{2}{|c|}{ CSM (ten sources) } & \multicolumn{2}{|c|}{$\mathrm{CSM} \times \mathrm{B}^{2}$} \\
\hline & 1 & 2 & 3 & 4 & 5 & 6 & 7 & 8 & 9 & 10 & & $\mathrm{SEM}^{3}$ & $\mathrm{p}$-value & SEM $^{3}$ & $\mathrm{p}$-value \\
\hline GE intake (kcal) & 6,336 & 6,270 & 6,415 & 6,506 & 6,376 & 6,423 & 6,502 & 6,482 & 6,791 & 6,639 & 6,400 & 49.68 & 0.4404 & 87.80 & 0.6857 \\
\hline GE in feces (kcal) & $895^{\mathrm{c}}$ & $1,070^{\mathrm{ab}}$ & $1,025^{\mathrm{abc}}$ & $1,002^{\mathrm{abc}}$ & $874^{\mathrm{c}}$ & $1,148^{\mathrm{a}}$ & $1,060^{\mathrm{ab}}$ & $973^{\mathrm{bc}}$ & $1,134^{\mathrm{ab}}$ & $1,114^{\mathrm{ab}}$ & 600 & 16.46 & $<0.0001$ & 64.43 & $<0.0001$ \\
\hline GE in urine (kcal) & 171 & 125 & 179 & 168 & 161 & 138 & 127 & 140 & 118 & 94 & 151 & 11.56 & 0.8470 & 10.19 & 0.6876 \\
\hline $\mathrm{DE}$ of the diet $(\mathrm{kcal} / \mathrm{kg})$ & 3,262 & 3,125 & 3,185 & 3,238 & 3,298 & 3,117 & 3,201 & 3,240 & 3,162 & 3,145 & 3,486 & 25.72 & 0.8534 & 68.00 & 0.0296 \\
\hline MEof the diet $(\mathrm{kcal} / \mathrm{kg})$ & 3,159 & 3,050 & 3,080 & 3,139 & 3,202 & 3,036 & 3,127 & 3,158 & 3,096 & 3,091 & 3,395 & 22.74 & 0.8836 & 65.03 & 0.0259 \\
\hline ATTD of GE $(\%)$ & $85.88^{\mathrm{ab}}$ & $82.89^{\mathrm{cd}}$ & $84.01^{\mathrm{bcd}}$ & $84.62^{\mathrm{abc}}$ & $86.26^{\mathrm{a}}$ & $82.12^{\mathrm{d}}$ & $83.65^{\mathrm{cd}}$ & $85.02^{\mathrm{abc}}$ & $83.30^{\mathrm{cd}}$ & $83.22^{\mathrm{cd}}$ & 90.52 & 0.23 & $<0.0001$ & 1.04 & 0.0005 \\
\hline $\mathrm{N}$ intake (g) & $49.51^{\mathrm{cd}}$ & $46.39^{d}$ & $53.68^{\mathrm{bc}}$ & $57.61^{\mathrm{ab}}$ & $51.77^{\mathrm{c}}$ & $56.33^{\mathrm{ab}}$ & $56.77^{\mathrm{ab}}$ & $57.58^{\mathrm{ab}}$ & $59.62^{\mathrm{a}}$ & $57.98^{\mathrm{ab}}$ & 40.42 & 0.69 & $<0.0001$ & 1.85 & $<0.0001$ \\
\hline $\mathrm{N}$ in feces $(\mathrm{g})$ & $7.27^{\mathrm{b}}$ & $7.14^{\mathrm{b}}$ & $7.74^{\mathrm{ab}}$ & $7.85^{\mathrm{ab}}$ & $7.69^{\mathrm{ab}}$ & $8.83^{\mathrm{a}}$ & $8.69^{\mathrm{a}}$ & $7.91^{\mathrm{ab}}$ & $8.92^{\mathrm{a}}$ & $8.00^{\mathrm{ab}}$ & 4.30 & 0.14 & 0.0145 & 0.54 & $<0.0001$ \\
\hline $\mathrm{N}$ in urine $(\mathrm{g})$ & 19.15 & 16.87 & 15.23 & 18.30 & 14.46 & 15.88 & 16.24 & 19.33 & 24.38 & 22.69 & 12.15 & 1.49 & 0.9009 & 1.62 & 0.0577 \\
\hline $\mathrm{N}$ digested (g) & $42.24^{\mathrm{cd}}$ & $39.25^{\mathrm{d}}$ & $45.95^{\mathrm{abc}}$ & $49.76^{\mathrm{a}}$ & $44.08^{\mathrm{bc}}$ & $47.51^{\mathrm{ab}}$ & $48.07^{\mathrm{ab}}$ & $49.68^{\mathrm{a}}$ & $50.70^{\mathrm{a}}$ & $49.99^{\mathrm{a}}$ & 36.12 & 0.63 & $<0.0001$ & 1.51 & $<0.0001$ \\
\hline $\mathrm{N}$ retained $(\mathrm{g})$ & 23.09 & 22.38 & 30.72 & 31.46 & 29.62 & 31.63 & 31.83 & 30.35 & 26.32 & 27.30 & 23.97 & 1.42 & 0.7944 & 1.43 & 0.1175 \\
\hline ATTD of N (\%) & 85.30 & 84.52 & 85.59 & 86.37 & 85.11 & 84.31 & 84.60 & 86.26 & 85.04 & 86.20 & 89.18 & 0.24 & 0.4854 & 1.01 & 0.0535 \\
\hline $\mathrm{N}$ retention (\%) & 46.66 & 49.57 & 57.61 & 54.86 & 57.18 & 56.38 & 56.22 & 52.62 & 44.11 & 47.06 & 59.42 & 2.59 & 0.9567 & 3.08 & 0.2540 \\
\hline
\end{tabular}

${ }^{1}$ Each CSM diet contained one of the ten CSM sources. Source 1, 2, 3, 4, 5, 6, 7, 8, 9 and 10 were collected from Shandong, Shanxi, Hubei, Hunan, Sichuan, Henan, Hebei, Xinjiang, Anhui, and Liaoning province of China, respectively.

${ }^{2} \mathrm{GE}=$ Gross energy; DE = Digestible energy; ME = Metabolizable energy; ATTD = Apparent total tract digestibility; $\mathrm{B}=\mathrm{Basal}$ diet.

${ }^{3} \mathrm{SEM}=$ Standard error of means. Means within the same row lacking a common superscript letter differ significantly ( $\mathrm{p}<0.05$ ). 
Table 5. Energy content and ATTD of GE in ten different cottonseed meals (CSM) sources

\begin{tabular}{|c|c|c|c|c|c|c|c|c|c|c|c|c|}
\hline \multirow{2}{*}{ Items $^{2}$} & \multicolumn{10}{|c|}{ CSM source $^{1}$} & \multirow{2}{*}{ SEM $^{3}$} & \multirow{2}{*}{$\mathrm{p}$-value } \\
\hline & 1 & 2 & 3 & 4 & 5 & 6 & 7 & 8 & 9 & 10 & & \\
\hline$\overline{\mathrm{DE}}$ (kcal/kg as-fed) & $2,453^{\mathrm{a}}$ & $1,697^{\mathrm{c}}$ & $1,973^{\mathrm{bc}}$ & $2,255^{\mathrm{ab}}$ & $1,990^{\mathrm{bc}}$ & $1,690^{\mathrm{c}}$ & $2,092^{\mathrm{ab}}$ & $2,263^{\mathrm{ab}}$ & $2,438^{\mathrm{a}}$ & $2,353^{\mathrm{ab}}$ & 44.12 & $<0.0001$ \\
\hline $\mathrm{DE}(\mathrm{kcal} / \mathrm{kg} \mathrm{DM})$ & $2,701^{\mathrm{ab}}$ & $1,870^{\mathrm{d}}$ & $2,167^{\mathrm{cd}}$ & $2,482^{\mathrm{abc}}$ & $2,173^{\mathrm{cd}}$ & $1,856^{\mathrm{d}}$ & $2,291^{\mathrm{bc}}$ & $2,482^{\mathrm{abc}}$ & $2,730^{\mathrm{a}}$ & $2,573^{\mathrm{abc}}$ & 49.05 & $<0.0001$ \\
\hline $\mathrm{ME}$ (kcal/kg as-fed) & $2,301^{\mathrm{a}}$ & $1,690^{\mathrm{b}}$ & $1,834^{\mathrm{ab}}$ & $2,078^{\mathrm{ab}}$ & $1,910^{\mathrm{ab}}$ & $1,618^{\mathrm{b}}$ & $2,063^{\mathrm{ab}}$ & $2,102^{\mathrm{ab}}$ & $2,254^{\mathrm{a}}$ & $2,294^{\mathrm{a}}$ & 47.00 & 0.0008 \\
\hline $\mathrm{ME}(\mathrm{kcal} / \mathrm{kg} \mathrm{DM})$ & $2,534^{\mathrm{a}}$ & $1,863^{\mathrm{b}}$ & $2,015^{\mathrm{ab}}$ & $2,288^{\mathrm{ab}}$ & $2,086^{\mathrm{ab}}$ & $1,778^{\mathrm{b}}$ & $2,259^{\mathrm{ab}}$ & $2,306^{\mathrm{ab}}$ & $2,524^{\mathrm{a}}$ & $2,509^{\mathrm{a}}$ & 52.07 & 0.0007 \\
\hline ATTD of GE (\%) & $59.45^{\mathrm{a}}$ & $42.08^{\mathrm{c}}$ & $47.81^{\mathrm{bc}}$ & $55.85^{\mathrm{ab}}$ & $48.78^{\mathrm{bc}}$ & $41.37^{\mathrm{c}}$ & $50.18^{\mathrm{bc}}$ & $54.96^{\mathrm{ab}}$ & $60.47^{\mathrm{a}}$ & $55.91^{\mathrm{ab}}$ & 1.06 & $<0.0001$ \\
\hline ME/DE (\%) & 93.81 & 99.58 & 92.93 & 92.39 & 97.05 & 95.24 & 98.61 & 93.07 & 92.13 & 97.26 & 1.23 & 0.8613 \\
\hline
\end{tabular}

${ }^{1}$ Source 1, 2, 3, 4, 5, 6, 7, 8, 9 and 10 were collected from Shandong, Shanxi, Hubei, Hunan, Sichuan, Henan, Hebei, Xinjiang, Anhui, and Liaoning province of China, respectively.

${ }^{2} \mathrm{GE}=$ Gross energy; DE = Digestible energy; ME = Metabolizable energy; ATTD = Apparent total tract digestibility; ME/DE = The ratio of ME to DE.

${ }^{3} \mathrm{SEM}=$ Standard error of means. Means within the same row lacking a common superscript letter differ significantly ( $\mathrm{p}<0.05$ ).

ME, respectively). Dietary fiber was also a good predictor for DE and ME. Dietary fiber was estimated from different analytical procedures, so NDF, ADF and ADL were tested separately in the regression analysis (Table 7). Among the three fiber fractions, NDF had the highest accuracy to predict DE and ME. Meanwhile, DE and ME could also be predicted based on the EE content. The accuracy of the equations was improved with the inclusion of both the $\mathrm{CP}$ and $\mathrm{EE}$ factors. The best fit equations were obtained for $\mathrm{DE}$ and ME, which were: $\mathrm{DE}, \mathrm{kcal} / \mathrm{kg} \mathrm{DM}=670.14+31.12 \mathrm{CP}$ +659.15 EE with $\mathrm{R}^{2}=0.82, \mathrm{RSD}=172.02, \mathrm{p}<0.05$; and $\mathrm{ME}, \mathrm{kcal} / \mathrm{kg} \mathrm{DM}=843.98+25.03 \mathrm{CP}+673.97 \mathrm{EE}$ with $\mathrm{R}^{2}=$ $0.84, \mathrm{RSD}=144.79, \mathrm{p}<0.05$. The suitability of these two prediction models was tested by validation samples, which consisted of source 4 and 8 (Table 8). The maximum absolute difference and relative deviation between in vivo DE determinations and predicted DE values was 271 $\mathrm{kcal} / \mathrm{kg}$ and $5.77 \%$, respectively, while these two values for ME were $183 \mathrm{kcal} / \mathrm{kg}$ and $4.17 \%$, respectively.

\section{DISCUSSION}

\section{Chemical composition of CSM sources}

The chemical composition of CSM sources was quite variable for all criteria in the current study. One reason may be that the soil and environment conditions and the cultivars of cotton plants were different in these regions of China, which led to a large variation in the quality of cottonseed, and when the cottonseed meals were produced from these cottonseeds by proper processing, differences in their quality may be observed. Although the same pre-press extraction method was used, there may be some differences in the treatment temperature and solvent used during the production of cottonseed oil among the cottonseed meal processing plants, also leading to the variation in the quality of cottonseed meals (Lea and Hannan, 1949; AndersonHafermann et al., 1993).

The NDF, ADF, ADL content varied largely among the CSM sources. It can be partly explained by the different levels of hulls added to the final cottonseed meal products (Stein et al., 2006). The content of CP was relatively high while the contents of cell wall fractions were low, agreeing with previous reports (Tanksley et al., 1981; Batterham et al., 1990). The concents of CP in sources 1,9 , and 10 $(50.85,49.64$, and $54.01 \%$, respectively) were a little higher than previously published values (Tanksley et al., 1981; Batterham et al., 1990; NRC, 1998; Prawirodigdo et al., 1998; Li et al., 1999). The contents of ether extract in all of the CSM were much lower than excepted values (Tanksley et al., 1981; NRC, 1998), which indicates that more

Table 6. Correlation coefficients between chemical composition and DE and ME of calibration cottonseed meal (CSM) samples ${ }^{1}$

\begin{tabular}{|c|c|c|c|c|c|c|c|c|c|}
\hline Item & $\mathrm{CP}$ & $\mathrm{EE}$ & $\mathrm{NDF}$ & $\mathrm{ADF}$ & ADL & Ash & GE & $\mathrm{DE}$ & $\mathrm{ME}$ \\
\hline$\overline{\mathrm{EE}}$ & 0.69 & & & & & & & & \\
\hline $\mathrm{NDF}$ & -0.93 & -0.79 & & & & & & & \\
\hline $\mathrm{ADF}$ & -0.93 & -0.74 & 0.98 & & & & & & \\
\hline $\mathrm{ADL}$ & -0.95 & -0.76 & 0.94 & 0.92 & & & & & \\
\hline Ash & -0.76 & -0.95 & 0.85 & 0.81 & 0.86 & & & & \\
\hline GE & 0.90 & 0.54 & -0.77 & -0.77 & -0.83 & -0.66 & & & \\
\hline $\mathrm{DE}$ & 0.86 & 0.81 & -0.83 & -0.83 & -0.80 & -0.73 & 0.63 & & \\
\hline $\mathrm{ME}$ & 0.85 & 0.84 & -0.82 & -0.82 & -0.81 & -0.77 & 0.68 & 0.98 & \\
\hline FG & 0.21 & 0.64 & -0.28 & -0.15 & -0.30 & -0.61 & 0.35 & 0.20 & 0.27 \\
\hline
\end{tabular}

${ }^{1} \mathrm{CP}=$ Crude protein, $\mathrm{EE}=$ Ether extract, $\mathrm{NDF}=$ Neutral detergent fiber, $\mathrm{ADF}=$ Acid detergent fiber, $\mathrm{ADL}=$ Acid detergent lignin, GE $=$ Gross energy, $\mathrm{DE}=$ Digestible energy, $\mathrm{ME}=$ Metabolizable energy, $\mathrm{FG}=$ Free gossypol; Correlation whose absolute value is above 0.69 is different from zero $(\mathrm{p}<0.05)$. 
Table 7. Prediction equations of digestible and metabolizable energy ( $\mathrm{kcal} / \mathrm{kg} \mathrm{DM})$ from chemical composition of calibration cottonseed meal samples (CSM) $(\% \text {, as dry matter basis })^{1}$

\begin{tabular}{|c|c|c|c|c|}
\hline$\overline{\text { No. }}$ & Equation & $\overline{\mathrm{R}^{2}}$ & $\mathrm{RSD}^{2}$ & p-value \\
\hline 1 & $\mathrm{DE}=171.64+46.54 \mathrm{CP}$ & 0.73 & 192.46 & 0.01 \\
\hline 2 & $\mathrm{DE}=1,893.05+1,291.80 \mathrm{EE}$ & 0.65 & 220.54 & 0.02 \\
\hline 3 & $\mathrm{DE}=3,890.43-47.05 \mathrm{NDF}$ & 0.70 & 205.61 & 0.01 \\
\hline 4 & $\mathrm{DE}=3,679.86-62.95 \mathrm{ADF}$ & 0.69 & 207.71 & 0.01 \\
\hline 5 & $\mathrm{DE}=3,194.74-85.17 \mathrm{ADL}$ & 0.64 & 223.45 & 0.02 \\
\hline 6 & $\mathrm{DE}=670.14+31.12 \mathrm{CP}+659.15 \mathrm{EE}$ & 0.82 & 172.02 & 0.01 \\
\hline 7 & $\mathrm{DE}=1,303.01+32.95 \mathrm{CP}-15.09 \mathrm{NDF}$ & 0.74 & 207.20 & 0.03 \\
\hline 8 & $\mathrm{DE}=1,142 \cdot 27+34 \cdot 18 \mathrm{CP}-18.49 \mathrm{ADF}$ & 0.74 & 207.73 & 0.03 \\
\hline 9 & $\mathrm{DE}=3,861.78+38.79 \mathrm{CP}-487.39 \mathrm{Ash}$ & 0.75 & 204.69 & 0.03 \\
\hline 10 & $\mathrm{DE}=3,102.28+628.83 \mathrm{EE}-29.58 \mathrm{NDF}$ & 0.75 & 202.49 & 0.03 \\
\hline 11 & $\mathrm{DE}=2,944.90+682.11 \mathrm{EE}-39.19 \mathrm{ADF}$ & 0.77 & 194.60 & 0.02 \\
\hline 12 & $\mathrm{DE}=2,560.99+750.67 \mathrm{EE}-47.29 \mathrm{ADL}$ & 0.73 & 210.68 & 0.04 \\
\hline 13 & $\mathrm{ME}=334.27+40.80 \mathrm{CP}$ & 0.72 & 174.40 & 0.01 \\
\hline 14 & $\mathrm{ME}=1,827.81+1,182.93 \mathrm{EE}$ & 0.70 & 181.63 & 0.01 \\
\hline 15 & $\mathrm{ME}=3,579.52-40.80 \mathrm{NDF}$ & 0.67 & 189.85 & 0.01 \\
\hline 16 & $\mathrm{ME}=3,405.92-55.00 \mathrm{ADF}$ & 0.67 & 188.70 & 0.01 \\
\hline 17 & $\mathrm{ME}=2,998.56-75.98 \mathrm{ADL}$ & 0.65 & 194.66 & 0.02 \\
\hline 18 & $\mathrm{ME}=843.98+25.03 \mathrm{CP}+673.97 \mathrm{EE}$ & 0.84 & 144.79 & 0.01 \\
\hline 19 & $\mathrm{ME}=1,062.02+32.06 \mathrm{CP}-9.70 \mathrm{NDF}$ & 0.73 & 189.39 & 0.04 \\
\hline 20 & $\mathrm{ME}=1,109.61+30.93 \mathrm{CP}-14.77 \mathrm{ADF}$ & 0.73 & 188.87 & 0.04 \\
\hline 21 & $\mathrm{ME}=5,460.12+30.04 \mathrm{CP}-677.01 \mathrm{Ash}$ & 0.76 & 177.71 & 0.03 \\
\hline 22 & $\mathrm{ME}=2,687.90+711.39 \mathrm{EE}-21.04 \mathrm{NDF}$ & 0.76 & 175.51 & 0.03 \\
\hline 23 & $\mathrm{ME}=2,944.90+682.11 \mathrm{EE}-39.19 \mathrm{ADF}$ & 0.79 & 165.78 & 0.02 \\
\hline 24 & $\mathrm{ME}=2,372.24+741.87 \mathrm{EE}-38.55 \mathrm{ADL}$ & 0.77 & 174.07 & 0.03 \\
\hline
\end{tabular}

${ }^{1} \mathrm{CP}=$ Crude protein, $\mathrm{EE}=$ Ether extract, $\mathrm{NDF}=$ Neutral detergent fiber, $\mathrm{ADF}=$ Acid detergent fiber, $\mathrm{ADL}=\mathrm{Acid}$ detergent lignin, $\mathrm{DE}=\mathrm{Digestible}$ energy, ME $=$ Metabolizable energy.

${ }^{2}$ RSD which is the root mean square of the error that applies to the whole model (Cozannet et al., 2010).

effective solvent had been used to extract the oil from cottonseed more entirely, and, as a result, the GE of the CSM were lower than the values obtained by Batterham et al. (1990). With a high content of Phy-P, the availability of the $\mathrm{P}$ in these CSM was low, in accordance with Eeckhout and Paepe (1994) and NRC. (1998). With the proper treatment temperature and solvent used during the processing of CSM, the free gossypol contents of the CSM sources were relatively low, ranging from 214.30 to 395.05 $\mathrm{mg} / \mathrm{kg}$. The ethanol vapor used as a solvent could reduce free gossypol to a safe level in CSM for feeding as a general animal feed protein source (Hron et al., 1996). Cooking temperature could aslo influence the free gossypol content in CSM. Reduction in free gossypol during cooking was due to binding with other components while that occurring during pre-pressing and solvent extraction resulted mainly from removal of gossypol in the pre-pressed and solventextracted oil (Pons et al., 1955).

\section{Energy and nitrogen digestibility}

It has been suggested that the presence of fiber could increase the endogenous secretions of $\mathrm{CP}$ and fat associated with the increasing microbial mass, as a result, the digestion of CP and fat was reduced (Sauer and Ozimek, 1986; Noblet and Perez, 1993). With greater fiber contents in the CSM diets compared with the basal diet, more energy

Table 8. Comparison of DE and ME contents in validation cottonseed meal (CSM) samples determined by using in vivo method and prediction models (as dry matter basis) ${ }^{1}$

\begin{tabular}{|c|c|c|c|c|c|c|c|c|}
\hline \multirow{2}{*}{$\begin{array}{l}\text { CSM } \\
\text { source }^{2}\end{array}$} & \multirow{2}{*}{$\begin{array}{l}\text { Determined DE } \\
\quad(\mathrm{kcal} / \mathrm{kg})\end{array}$} & \multicolumn{3}{|c|}{$\mathrm{DE}=670.14+31.12 \mathrm{CP}+659.15 \mathrm{EE}$} & \multirow{2}{*}{$\begin{array}{c}\text { Determined } \\
\mathrm{ME}(\mathrm{kcal} / \mathrm{kg})\end{array}$} & \multicolumn{3}{|c|}{$\mathrm{ME}=843.98+25.03 \mathrm{CP}+673.97 \mathrm{EE}$} \\
\hline & & $\begin{array}{l}\text { Predicted DE } \\
(\mathrm{kcal} / \mathrm{kg})\end{array}$ & $\begin{array}{l}\text { Difference, } \\
(\mathrm{kcal} / \mathrm{kg})\end{array}$ & $\begin{array}{c}\text { Relative } \\
\text { deviation (\%) }\end{array}$ & & $\begin{array}{l}\text { Predicted DE } \\
(\mathrm{kcal} / \mathrm{kg})\end{array}$ & $\begin{array}{l}\text { Difference } \\
(\mathrm{kcal} / \mathrm{kg})\end{array}$ & $\begin{array}{c}\text { Relative } \\
\text { deviation (\%) }\end{array}$ \\
\hline 4 & 2,482 & 2,211 & 271 & 5.77 & 2,288 & 2,105 & 183 & 4.17 \\
\hline 8 & 2,482 & 2,337 & 145 & 3.01 & 2,306 & 2,228 & 78 & 1.72 \\
\hline
\end{tabular}

${ }^{1} \mathrm{CP}=$ Crude protein, $\mathrm{EE}$ = Ether extract, $\mathrm{DE}=$ Digestible energy, ME = Metabolizable energy.

${ }^{2}$ Source 4 and 8 were collected from Hunan and Xinjiang province of China, respectively. 
excreted from feces was expected, thus making the energy values greater in the basal diet than that of CSM diets (Ren et al., 2011). It was also reported that energy digestibility was negatively affected by the dietary fiber content, especially for NDF (Noblet and Perez, 1993), which may be the reason that the basal diet had greater energy digestibility than CSM diets. A similar situation was also observed among the diets containing different CSM sources.

The results of current experiment indicate that the DE and ME content in the ten CSM sources ranges from 1,856 to $2,730 \mathrm{kcal} / \mathrm{kg} \mathrm{DM}$ and 1,778 to $2,534 \mathrm{kcal} / \mathrm{kg} \mathrm{DM}$, respectively. The average $\mathrm{DE}$ and $\mathrm{ME}$ contents $(2,332$ and $2,198 \mathrm{kcal} / \mathrm{kg} \mathrm{DM}$, respectively) for the ten CSM sources are lower than the values recommended by NRC (1998), the reason for this may be the extremely low EE levels in the CSM sources used in this experiment (Noblet and Perez, 1993; Ren et al., 2011). Meanwhile, because of the differences in CP and cell well fractions levels, the DE and ME contents were also different among the ten CSM sources (Noblet and Perez, 1993).

The ME to DE ratios varied from 92.13 to $99.58 \%$ among the ten CSM sources. The average ME to DE ratio $(95.21 \%)$ is similar with the previously published value of 96\% (Noblet and Perez, 1993; Fairbairn et al., 1999). Thus, because it is difficult to collect the urine entirely and determine the energy value of urine accurately in the digestion-metabolism experiment, we suggest that the ME value can be replaced by the DE value in the energy system of pigs to some extent.

\section{Correlations and prediction equations}

The results of this study indicated that the variability of chemical composition in CSM collected from different regions of China could contribute to the difference of DE and $\mathrm{ME}$ content. A number of prediction equations for $\mathrm{DE}$ and ME contents of feed ingredients and diets have been successfully developed (Just et al., 1984; Noblet and Perez, 1993; Fairbairn et al., 1999; Kim et al., 2009; Olukosi and Adeola, 2009; Cozannet et al., 2010; Anderson et al., 2012). However, the models obtained from one hundred and fourteen diets (Noblet and Perez, 1993) are unsuitable when applied to a certain ingredient. The best equations for DE and ME in barley (Fairbairn et al., 1999) and wheat-DDGS (Cozannet et al., 2010) contained fiber component, while the prediction equations for $\mathrm{ME}$ in meat and bone meal used other factors, such as GE, CP, P, Ca, and ash (Olukosi and Adeola, 2009). Therefore, the prediction equations for estimating DE and ME contents in CSM fed to growing pigs should be established based on the measured data of CSM.

With the correlation and regression analysis, the prediction models were mainly established according to the significant linear relationships between DE, ME and the chemical composition of CSM (Table 7). The results in Table 6 clearly showed that CP and EE content were positively correlated with DE and ME, while ash and fiber content had a negative effect. In this study, CP was the most significant factor affecting the DE and ME variation. It was likely because CSM was usually used as a protein source in swine feed with a high protein level and the negative correlation between $\mathrm{CP}$ and fiber was also very high as shown in Table 6. As a fraction of dietary fiber, NDF was also significant factor affecting the $\mathrm{DE}$ and ME variation. Simple analysis suggests that for every $1 \%$ increase in NDF content, the DE content would decrease by $1.21 \%$, slightly higher than that of Noblet and Le Goff (2001). ADF also displayed a significantly negative correlation with DE and ME. The reason for this may be that the insoluble fiber such as NDF and ADF are hardly digested by pigs, and thus, lower the energy content by replacing the digestible nutrients. The amount of $\mathrm{CP}$ and EE are negatively affected by the fiber content in this study, which agrees with Noblet and Perez (1993) and Noblet and Le Goff (2001).

The results of the current study demonstrate that it is possible to estimate the DE and ME of CSM samples from their chemical composition. Considering the cost and repeatability of the required chemical analysis, Equations 6 and 18 (Table 7) are chosen as the best two equations with an acceptable accuracy when estimating $\mathrm{DE}$ and $\mathrm{ME}$ content of CSM. However, in order to improve the accuracy of the prediction models, more representative CSM sources should be used in further study.

\section{IMPLICATIONS}

An improved understanding of the energy variation and the ability to estimate energy content in individual feed ingredients would make the formulation of swine more precise. This study indicated that DE and ME contents of cottonseed meal could be predicted based on several chemical characteristics with an acceptable accuracy. A practical method for accurately estimating the energy values in cottonseed meal also would reduce feed costs and decrease amount of wasted nutrients.

\section{ACKNOWLEDGEMENTS}

This research was financially supported by National Key Technology R \& D Program in the 11th Five Year Plan of China (2006BAD12B01) and Special Public Sector Fund in Agriculture (200903006).

\section{REFERENCES}

Adeola, O. 2001. Digestion and balance techniques in pigs. Page 903 in Swine Nutrition, 2nd ed. A. J. Lewis and L. L. Southern, 
ed. CRC Press, Washington, DC, USA.

AOAC. 2000. Official methods of analysis, 17 Edition. Association of Official Analytical Chemists, Virginia, USA.

Anderson, P. V., B. J. Kerr, T. E. Weber, C. J. Ziemer and G. C. Shurson. 2012. Determination and prediction of digestible and metabolizable energy from chemical analysis of corn coproducts fed to growing pigs. J. Anim. Sci. 90:1242-1254.

Anderson-Hafermann, J. C., Y. Zhang and C. M. Parsons. 1993. Effects of processing on the nutritive quality of canola meal. Poult. Sci. 72:326-333.

Ash, M. and E. Dohlman. 2006. Oil crops situation and outlook yearbook. Electronic outlook report from the economic research service. U. S. Department of Agriculture.

Batterham, E. S., L. M. Andersen, D. R. Baigent and R. E. Darnell. 1990. A comparison of the availability and ileal digestibility of lysine in cottonseed and soya-bean meals for grower/finisher pigs. Br. J. Nutr. 64:663-677.

Brown, W. F. and F. M. Pate. 1997. Cottonseed meal or feather meal supplementation of ammoniated tropical grass hay for yearling cattle. J. Anim. Sci. 75:1666-1673.

Cozannet P., Y. Primot, C. Gady, J. P. Metayer, M. Lessire, F. Skiba and J. Noblet. 2010. Energy value of wheat distillers grains with solubles for growing pigs and adult sows. J. Anim. Sci. 88:2382-2392.

Cranston, J. J., J. D. Rivera, M. L. Galyean, M. M. Brashears, J. C. Brooks, C. E. Markham, L. J. McBeth and C. R. Krehbiel 2006. Effects of feeding whole cottonseed and cottonseed products on performance and carcass characteristics of finishing beef cattle. J. Anim. Sci. 84:2186-2199.

Eeckhout, W. and M. De Paepe. 1994. Total phosphorus, phytatephosphorus and phytase activity in plant feedstuffs. Anim. Feed Sci. Technol. 47:19-29.

Fairbairn, S. L., J. F. Patience, H. L. Classen and R. T. Zijlstra. 1999. The energy content of barley fed to growing pigs: characterizing the nature of its variability and developing prediction equations for its estimation. J. Anim. Sci. 77:15021512.

Fombad, R. B. and M. J. Bryant. 2004. An evaluation of the use of cottonseed cake in the diet of growing pigs. Trop. Anim. Health Prod. 36:295-305.

Gottlob, R. O., J. M. DeRouchey, M. D. Tokach, R. D. Goodband, S. S. Dritz, J. L. Nelssen, C. W. Hastad and D. A. Knabe. 2006. Amino acid and energy digestibility of protein sources of growing pigs. J. Anim. Sci. 84:1396-1402.

Hron, R. J., P. J. Wan and M. S. Kuk. 1996. Ethanol vapor deactivation of gossypol in cottonseed meal. J. Am. Oil Chem. Soc. 73:1337-1339.

Husby, F. M. and G. H. Kroening. 1971. Energy value of cottonseed meal for swine. J. Anim. Sci. 33:592-594.

Just, A., H. Jorgensen and J. A. Fernandez. 1984. Prediction of metabolizable energy for pigs on the basis of crude nutrients in the feeds. Livest. Prod. Sci. 11:105-128.

Kim, J. C., B. P. Mullan, J. M. Heo, A. Hernandez and J. R. Pluske. 2009. Variation in digestible energy content of Australian sweet lupins (Lupinus angustifolius $\mathrm{L}$.) and the development of prediction equations for its estimation. J. Anim. Sci. 87:25652573.

Knabe, D. A., D. C. LaRue, E. J. Gregg, G. M. Martinez and T. D. Tanksley. 1989. Apparent digestibility of nitrogen and amino acids in protein feedstuffs by growing pigs. J. Anim. Sci.
67:441-458.

Lea, C. H. and R. S. Hannan. 1949. The effect of activity of water, of $\mathrm{pH}$ and of temperature on the primary reaction between casein and glucose. Biochim. Biophys. Acta 3:313-325.

Li, D. F., X. X. Xu, S. Y. Qiao, C. T. Zheng, Y. Chen, X. S. Piao, In K. Han and P. Thacker. 2000. Growth performance of growing-finishing pigs fed diets supplemented with chinese cottonseed meal based on amino acid digestibilities. AsianAust. J. Anim. Sci. 13:521-527.

Littell, R. C., P. R. Henry and C. B. Ammerman. 1998. Statistical analysis of repeated data using SAS procedures. J. Anim. Sci. 76:1216-1231.

NRC. 1998. Nutrient requirement of pigs. 10th Edition. National Research Council, Academy Press. Washington, DC, USA.

Noblet, J. and J. M. Perez. 1993. Prediction of digestibility of nutrients and energy values of pig diets from chemical analysis. J. Anim. Sci. 71:3389-3398.

Noblet, J. and G. Le Goff. 2001. Effect of dietary fiber on the energy value of feeds for pigs. Anim. Feed Sci. Technol. 90:35-52.

Olukosi, O. A. and O. Adeola. 2009. Estimation of metabolizable energy content of meat and bone meal for swine. J. Anim. Sci. 87:2590-2599.

Papadopoulos, G., K. Fegeros and E. Ziras. 1987. Evaluation of greek cottonseed meal. 2. Use in rations for fattening pigs. Anim. Feed Sci. Technol. 18:303-313.

Pons, W. A. and J. D. Guthrie. 1949. Determination of free gossypol in cottonseed materials. J. Am. Oil Chem. Soc. 26:671-676.

Pons, W. A., F. H. Thurber and G. L. Hoffpauir. 1955. Prepresssolvent extraction of cottonseed, processing conditions and characteristics of products. J. Am. Oil Chem. Soc. 32:98-103.

Prawirodigdo, S., N. J. Gannon, R. J. van Barneveld, D. J. Kerton, B. J. Leury and R. Dunshea. 1998. Assessment of apparent ileal digestibility of amino acids and nitrogen in cottonseed and soyabean meals fed to pigs determined using ileal dissection under halothane anaesthesia or following carbon dioxide-stunning. Br. J. Nutr. 80:183-191.

Reddy, N. R., C. V. Balakrishnan and D. K. Salunkhe. 1978. Phytate phosphorus and mineral changes during germination and cooking of blackgram (Phaseolus mungo L.) seeds. J. Food Sci. 43:540-542.

Ren, P., Z. P. Zhu, B. Dong, J. J. Zang and L. M. Gong. 2011. Determination of energy and amino acid digestibility in growing pigs fed corn distillers' dried grains with solubles containing different lipid levels. Arch. Anim. Nutr. 65:303-319.

Robison, W. L. 1931. Cottonseed meal for pigs. J. Anim. Sci. 1931:227-232.

Sauer, W. C. and L. Ozimek. 1986. Digestibility of amino avids in swine: Results and their practical application: A Review. Livest. Prod. Sci. 15:367-387.

SAS. 1999. SAS user's guide: Statistics (Version 8.01 Ed). SAS Inst. Inc., Cary, N. C. USA.

Song, G. L., D. F. Li, X. S. Piao, F. Chi and W. J. Yang. 2003. Apparent ileal digestibility of amino acids and the digestible and metabolizable energy content of high-oil corn varieties and its effects on growth performance of pigs. Arch. Anim. Nutr. 57:297-306.

Stein, H. H., M. L. Gibson, C. Pedersen and M. G. Boersma. 2006. Amino acid and energy digestibilty in ten samples of distillers 
dried grain with solubles fed to growing pigs. J. Anim. Sci. 84:853-860

Tanksley, T. D., D. A. Knabe, K. Purser, T. Zebrowska and J. R. Corley. 1981. Apparent digestibily of amino acids and nitrogen in three cottonseed meals and one soybean meal. J. Anim. Sci. 52:769-777.

Tanksley, T. D. 1990. Cottonseed meal. In: Nontraditional Feed Sources for Use in Swine Production (Ed. P. A. Thacker and R. N. Kirkwood). Butterworths, Stoneham, MA. pp. 139-151.

Thiex, N. J., H. Manson, S. Anderson and J. A. Persson. 2002 Determination of crude protein in animal feed, forage, grain, and oilseeds by using block digestion with copper catalyst and steam distillation into boric acid: Collaborative study. J. AOAC Int. 85:309-317.
Thiex, N. J., S. Anderson and B. Gildemeister. 2003. Crude fat, diethyl ester extraction in feed, cereal grains, and forge (Randall/Soxtec/submersion method): Collaborative study. J. AOAC Int. 86:888-898.

Van Soest, P. J., J. B. Robertson and B. A. Lewis. 1991. Methods for dietary fiber, neutral detergent fiber, and non-starch polysaccharides in relation to animal nutrition. J. Dairy Sci. 74:3583-3597.

Wheeler, E. L. and R. E. Ferrel. 1971. A method for phytic acid determination in wheat and wheat fractions. Cereal Chem. 48:312-315.

Winterholl, S. J., D. L. Lalman, M. D. Hudson and C. L. Goad. 2009. Supplemental energy and extruded-expelled cottonseed meal as a supplemental protein source for beef cows consuming low-quality forage. J. Anim. Sci. 87:3003-3012. 